\title{
Case study on the impact of online schooling in a rural area during the emergency state (March- June 2019-2020 school year, Romania)
}

\author{
Mariana Viorela, Grigore-Filip (Șerban) ${ }^{1, *}$ \\ ${ }^{1}$ „Valahia” University of Târgovişte, Romania
}

\begin{abstract}
The spread of the Corona virus has brought about major changes in the world. Even before, this technology was an important presence in practically every sphere of our daily routine. There is a widespread assumption that the population existing in the rural areas is hesitant towards accustoming to modernization. This paper is an inquiry constructed on the base of a questionnaire designed to determine the standpoint of the parents having children enrolled at primary level school in relation to the compulsory new ICT tools at school and at home, the difficulties and their awareness of the array of possibilities offered by communication science. The research was conducted at the end of June 2021 and it focuses on the period from March to June (2019-2020 school year) when all schools in Romania were performing online classes. The pupils comprised in this respective case study attend „Oborani Elementary School (I-IV)”, a rural school with pupils from the preparatory level to the fourth grade from Vișina Village in Dâmbovița County, Romania.
\end{abstract}

Keywords: rural; parents; ICT; education.

JEL Classification: $I 21, I 29, O 30, O 33$

\section{A short intro to the subject matter}

The abilities to adapt and to learn are important defining features of humanity; education is a right recognized by law and also an obligation being compulsory up to a certain age. Its sole purpose is to shape the individuals in such a way that answer to the demands of society for economical growth. Its role is essential shaping each person and building the destiny of the society it belongs [1].

The process of education traditionally took place in a classroom involving educators and students in direct relation working together towards a common purpose.

Human society is characterized by its tendency to readjust itself according to financial, technological, social evolution and it undergoes this process through the process of education. From a global perspective we can assert that education is continuously updated by virtue of the new information and communication technology devices and applications.

The new changes in schooling, this progress of technical innovation affects both students and parents. When we refer to our country it is a known fact that regardless of the sector (city or countryside areas), the great majority of householders have Internet connection and possess different high-tech devices used for accessing the cyberspace for instance a personal computer or laptop also a smart phone, tablet, E-reader and more. 


\subsection{Schooling - globalised and virtualised}

When we discuss globalisation we actually invoke the natural tendency of contemporary society to create an international unification amongst countries affecting departments like politics, military, finance, social etc. This complicated movement will lead to a so-called equalization in living standards and general progress on a planetary scale.

Bearing in mind the sphere of formal schooling it is expected that this world wide integration tendency will ultimately lead to the substitution of the standard manner of accomplishing learning with an analogous virtual process which will be supported and confined by the mastery of digital competence. Schools and other providers of formal training would be converted into promoter and facilitator of certifying competences rather than what they represent nowadays. Thus and so, the function of the schooling organization of a nation will resume itself to qualifying the working population as "responding to the economical demands in the circumstances of global competition" [2].

Manifestations of this ongoing tendency of unifying nations are projects promoting mobility of educators, students and even pupils. Such obvious examples are Comenius, Erasmus, Leonardo officially supported by the European Union by which lager numbers of students received mobility each year starting with the year 1996.[3] .

The virtual feature arose as a result of the invention and development of new technology and humankind immediately adopted and assimilated this new way of life. However there are quite a few known negative aspects to this advance in technology, some important ones being acknowledged as causing mental dependence and undermining the process of education.

When considering education and schooling, that is formal education, the new ICT tools and devices embody many advantages though there are challenges emerging in regard of the time being and close future due to the evidence that students use it excessively to such a degree that some of them have lost the competence to spell correctly and to bear their own opinions.

Some fundamental characteristics of the virtual world are its independence of space and time (the act of communication can be established almost instantly no matter of the moment of its initiation and over passing any geographical distance). Also it has an easy access attribute that is data can be accessed from anywhere around the world by anyone who possesses a PC, a tablet or a smart mobile phone bound with an Internet connexion.

Institutions providing distance learning have emerged in the disservice to traditional schooling and there are many people who prefer this type of education because it grants them time and space autonomy and the prospect of having an occupation at the same time.

Else ways, the new information and communication innovations in technology in regards to the formal type of schooling has as objective the increase of the appeal to both students and educators and of course, of the educational outcome. The teacher is no longer sole resource and provider of data which the students have to fix in mind but it purpose has evolved into teaching to know how/ where to discover the necessary information, to discriminate between data and to develop critical thought. The future generations of employees have to meet the constantly changing demands of workforce marketplace by acquiring the competence and knowledge that have become defining in a modern society.

Researchers' analyses nowadays conclude that people normally spend a large amount of time employing devices of modern technology becoming addicted and resulting in modern types of health issues that can affect both the physical and/ or the mental. As a consequence limited usage of new technology devices is strongly suggested. 


\section{Investigation on the outlook of parents living in the countryside concerning modern education and ICT}

This study aimed at identifying the impact online schooling had on an average class group from a primary school from a rural area. Online schooling translates into the usage of only ICT tools in class to support teaching. It was carried on at Scoala Oborani, a recently modernized institution (having primary classes I-IV) in Dâmbovița concerning a class of $1^{\text {st }}$ graders. The number of subjects involved in the experiment is 40 parents of 20 children (aged from 7 to 8 years old) coming from mostly middle social class. The study compares the presence, the involvement and results the pupils had in the first foreign language studied at school (their 2-nd year) - in their case - English classes. The research aims to observe the educational process during the emergency state and to come up with ideas of improvement.

1. The extensiveness of the usage of the World Wide Web and the existence of the necessary hardware considering the present circumstances (pupils living in the countryside).

2. The impact of online schooling on attendance at class and on motivation.

3. The main issues during this period

The assumptions examined in this survey as well as the possible problems are presented below.

Assumption 1: Most households own hardware tools and also are fitted with Internet access.

Assumption 2: The partakers in the case study consider that the devices and applications/platforms are easy to use by 8 year olds.

Assumption 3: The online lessons were both attractive and educational for the target group.

The study will prove the assumptions presented either to be true or not after carefully analyzing the feedback received from the survey group.

The targeted population is represented by pupils (primary school, $1^{\text {st }}$ grade, on average 8 years old) enrolled in a country school unit in Dâmbovița County in Romania. There are two classes of the same educational level at Oborani School, so they have 40 pupils, grade $1^{\text {st }} \mathrm{A}$ and $1^{\text {st }} \mathrm{B}$. This experiment has involved the pupils attending 1st grade A. The sampling group is composed of 40 mothers and fathers and the interaction was mostly on the telephone. Concerning the manner of electing the participants we can state that all targeted population participated in the survey. The questionnaire was carried out by means of the point of view survey and it represents rather a quantitative analysis applying a questionnaire instrument.

The point of the inquiry is to determine the attitude of parents living in the countryside about the large-scale usage of NICT in the everyday life of their children and in particular its employment in learning. The questioning was nominal administered in a direct, face-to-face manner. In order to determine the grade of concern of certain principles, the Five Step Semantic Differential Scale was applied. The survey's data were rendered using Microsoft Office Excel. residence?

Inquiry1. Do you have a connection to the World Wide Web at your

Table 1. The presence of WWW connection at the respondents' residence. Source: author elaborated.

\begin{tabular}{|l|l|}
\hline Answer & Percentage \\
\hline
\end{tabular}




\begin{tabular}{|l|l|}
\hline Yes & 90 \\
\hline No & 10 \\
\hline
\end{tabular}

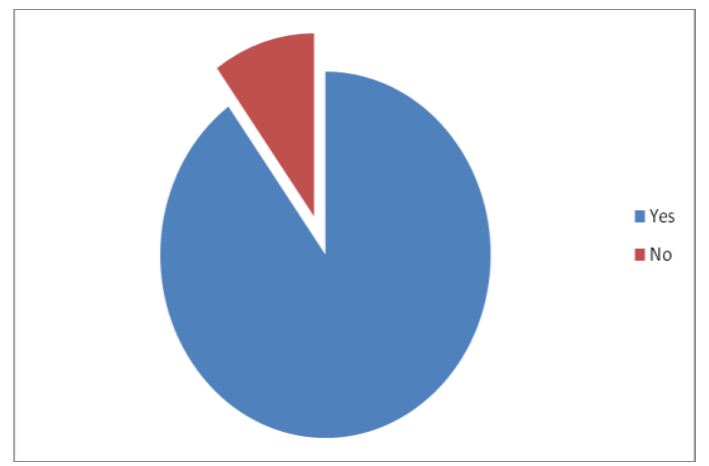

Figure 1. The presence of WWW connection at the respondents' residence.

Source: author elaborated.

The conclusion here is that the majority of the participants do have an Internet connection at their residence (90 percent).

Inquiry 2. Does your child (/children) possess (at your residence) a single device or more from the ones specified below?

Table 2. The devices accessible at the residence. Source: author elaborated.

\begin{tabular}{|l|l|}
\hline Answer & Percentage \\
\hline \hline IPad/Tablet & 10 \\
\hline \hline Smartphone & 85 \\
\hline Computer/PC & 12,5 \\
\hline & \\
\hline More than one & 7,5 \\
\hline
\end{tabular}




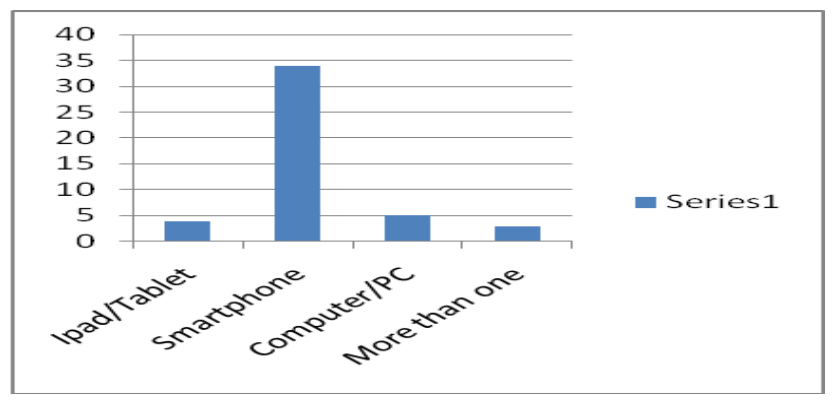

Figure 2. The devices accessible at the residence. Source: author elaborated.

According to the representation of the answers we recognize that the PC and the smart phone as the most favored; contrarily a small number of participants own tablets and iPads.

Inquiry 3. The number of hours that your offspring reserves to utilizing information and technology tools.

Table 3. The number of hours allotted by children to the utilization of technical devices. Source: author eleaborated.

\begin{tabular}{|c|c|}
\hline Answer & Percentage \\
\hline None & 0 \\
\hline About 2 hours & 37,5 \\
\hline About 4 hours & 10 \\
\hline More than 4 hours & 0 \\
\hline I am not sure & 42,5 \\
\hline
\end{tabular}

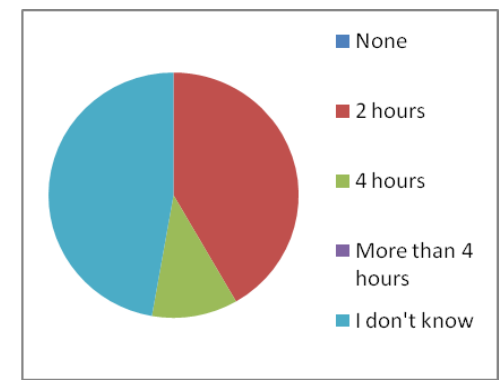

Figure 3. The number of hours allotted by children to utilization of technical devices. Source: author elaborated.

The result of this inquiry is that the largest part of the pupils allot on average two to four hours daily to employing modern technical devices. Inquiry 4 . The frequency of usage of modern gadgets particularly for school assignments or research. 
Table 4. The frequency of usage of modern tools for school work. Source: author elaborated.

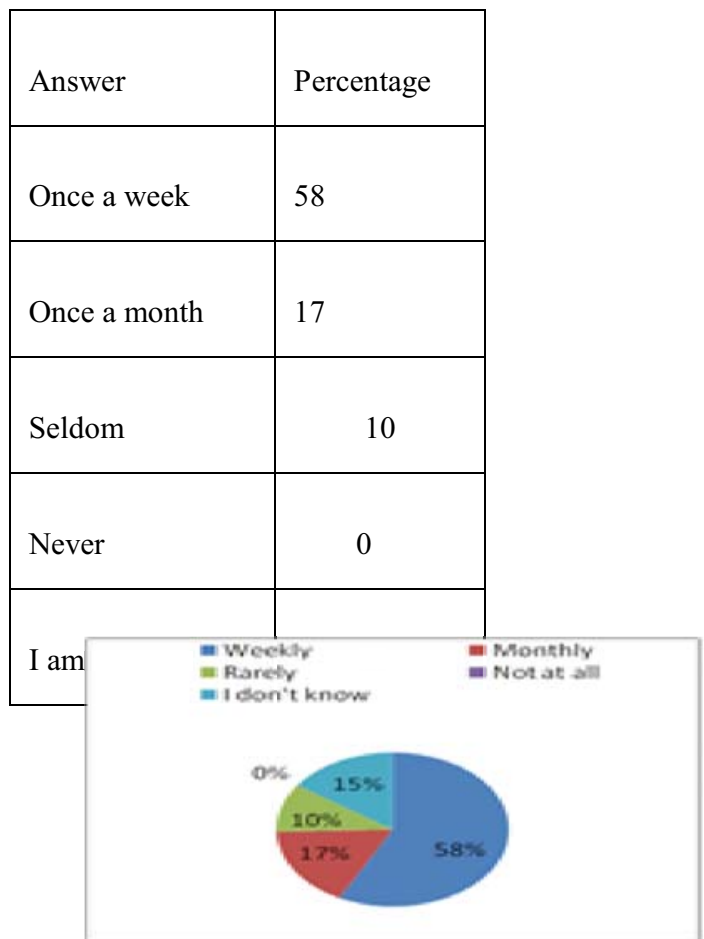

Figure 4. The frequency of usage of modern tools for school work. Source: author elaborated.

After studying the replies, we conclude that the biggest part of the participants recognize that their young utilize technical gadgets weekly for school work, a small number - once a month and few responded seldom. Still, there is a significant percentage of respondents that cannot appreciate the item examined in this inquiry.

Inquiry 5. Do you favor the effectiveness of technical tools during classes?

Table 5. The effectiveness of utilizing technical tools during classes. Source: author elaborated.

\begin{tabular}{|l|c|}
\hline Answer & Percentage \\
\hline Very utile & 31 \\
\hline Utile & 54 \\
\hline Not utile & 5 \\
\hline & 10 \\
\hline
\end{tabular}


Figure 5. The effectiveness of utilizing technical tools during classes. Source: author elaborated.

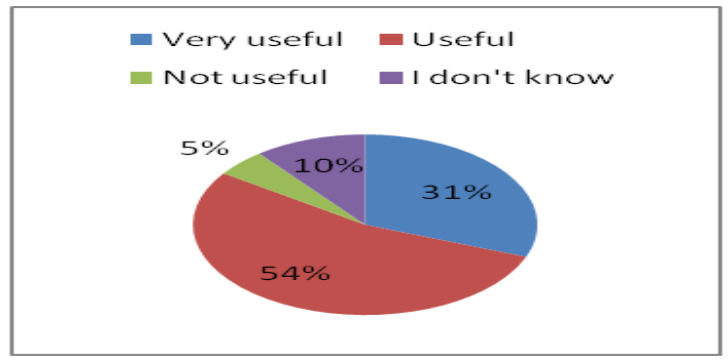

The greatest number of participants agrees that utilizing technical tools during classes is effective in training and learning.

Inquiry 6. Do you consider the online classes to be easy to accessible?

Table 6. The accessibility of online classes in the viewpoint of the participants in the survey. Source: author elaborated.

\begin{tabular}{|l|c|}
\hline Answer & Percentage \\
\hline Very easy to access & 0 \\
\hline Accessible & 17 \\
\hline Difficult & 20 \\
\hline Very difficult & 53 \\
\hline & \\
\hline I don't know & 10 \\
\hline
\end{tabular}

Figure 6. The accessibility of online classes in the viewpoint of the participants in the survey. Source: author elaborated.

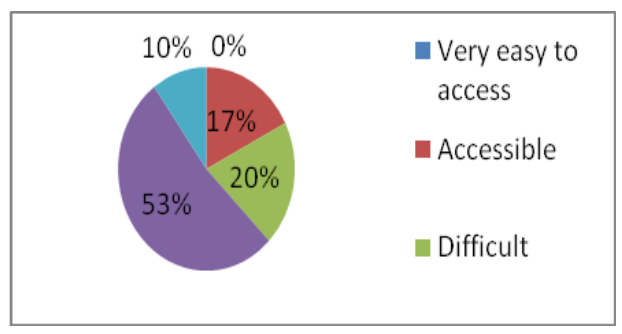

The biggest majority perceive online courses as being difficult or very difficult. Inquiry 7: Choose the one describing your child's attitude towards online classes. 
Table 7. Pupils' attitude towards online classes. Source: author elaborated.

\begin{tabular}{|l|c|}
\hline Answer & Percentage \\
\hline Better than face-to-face & 0 \\
\hline Acceptable & 15 \\
\hline Frustrating & 22 \\
\hline I prefer traditional/face-to-face & 63 \\
\hline I don't know & \\
\hline
\end{tabular}

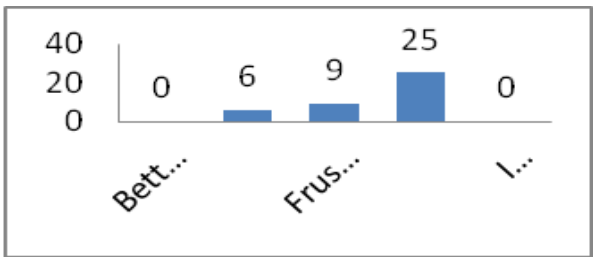

Figure 7. Pupils' attitude towards online classes. Source: author elaborated.

Inquiry8: What are the means you use to collaborate with the educational institution?

Table 8. Manners utilized to inform oneself about educational state. Source: author elaborated.

\begin{tabular}{|l|c|}
\hline Answer & Percentage \\
\hline Assembly /Meetings & 56 \\
\hline Phone & 27 \\
\hline $\begin{array}{l}\text { Social groups (what's up/ } \\
\text { messenger etc) }\end{array}$ & 17 \\
\hline Electronic school summary & 0 \\
\hline & \\
\hline Institution webpage & 0 \\
\hline
\end{tabular}




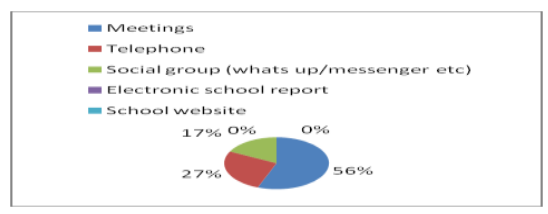

Figure 8. Ways of collaborating with the institution. Source: author elaborated.

The results of this inquiry mirror that the greatest number of participants favors the typical educator -parent assembly, a number of respondents choose finding out the educational report by telephone calls. The final two options have not been adopted on the count of not being present in our school unit.

Inquiry 9 . What is your age group?

Table 9. The participants'age. Source: author elaborated.

\begin{tabular}{|c|c|}
\hline Answer & Percentage \\
\hline 30 or younger & 95 \\
\hline $31-40$ & 5 \\
\hline $41-45$ & 0 \\
\hline & \\
\hline & 0 \\
\hline
\end{tabular}

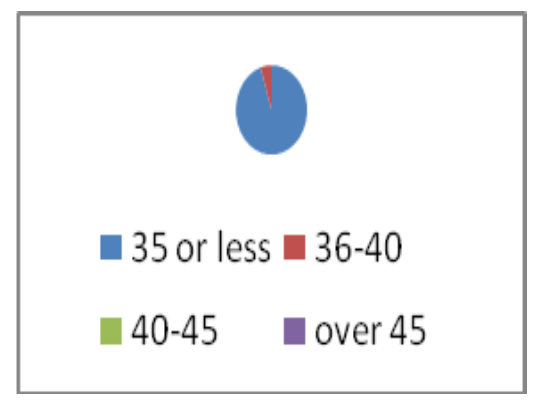

Figure 9. The participants 'age. Source: author elaborated.

Taking into consideration the replies provided to this inquiry, our observations are that the bulk of the participants are less than 30 years old allowing the presumption that they are more perceptive to the scientific advances. The attendance to online classes throughout this period and compared to the same period from the previous school year, same period is presented in the below table. 
Table 10. Comparison of attendance between years in the same period (March-June), 2018-2019 face-to-face classes and 2019-2020 online classes (mostly Zoom). Source: author elaborated.

\begin{tabular}{|l|l|}
\hline Attendance & Percentage \\
\hline $2018-2019$ & 62 \\
\hline $2019-2020$ & 38 \\
\hline
\end{tabular}

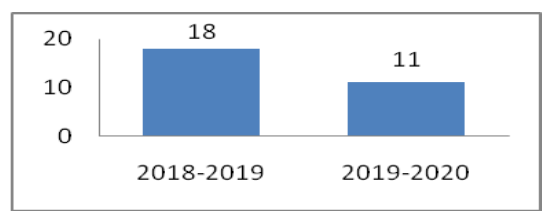

\section{Final remarks}

In conclusion, the participants in the study, mostly young parents of $1^{\text {st }}$ graders pupils enrolled at „Oborani Elementary School (I-IV)”, in the County of Dâmbovița, a public countryside educational institution declared having a WWW connection at their residence and owning a PC and minimum one smart phone used to surf the WEB. The greatest majority of the participants admit the improvements that the usage of NICT in the process of education brings about. They confirm that the pupils concerning our survey employ them every week for educational work. Despite being conscious about the evolution of science in formal training, the greatest mass would rather discuss with the educators in direct meetings. When referring to the existence of social groups for educational purposes, we acknowledge one group consisting of about 17 members, parents only. (for 20 pupils, one parent per one pupil, the rest of the parents stating that they don't have a mobile phone or it is too low quality and it doesn't allow this application to be installed). Further, we have to add that at the time of the study, the educational institution had no official webpage.

There are many issues regarding ranging from old mentalities to financial problems that do not allow the purchase of devices/ better devices. Due to the circumstances, we (parents, educators and students) have to employ good will and patiencealso the proper authorities should provide the necessary tools for educators and for students/ parents, education cannot pause because of the Corona virus.

\section{References}

1. Cantoni, L., Botturi, L., (2005). E-Learning Meeting Modular Education, the Case of Learning Objects, in Revue Suisse des sciences de l'éducation, 27e année, (2), Academic Press Fribourg, p. 45.

2. Cucoș, C. (coord.), (2009), Psihopedagogie pentru examenele de definitivare și grade didactice, Ediția a III-a revăzută și adăugită, Polirom.

3. Green, A., (1997). Education, Globalization and the Nation State, Macmillan Press Ltd., London 
4. Marinescu, V., (2009). Cercetarea în comunicare. Metode și tehnici, Editura C.H. Beck. București,

5. Rotaru, I., (2010). Comunicarea Virtuală. Impactul noilor tehnologii informaționale și comunicaționale în spațiul educaţional contemporan, București, Tritonic Publishing.

6. Scheau, I (coord.), (2004), Gândirea critică. Metode active de predare-învăţare, Editura Dacia, Cluj-Napoca.

7. Usher, R. \& Edwards, R., (1994), Postmodernism and Education: Different Voices, Different Worlds, Routledge Press, London, p175.

8. Valkenburgh, P. M., Piotrowski, J.T.,(2018). Plugged In. How Media Attract and Affect Youth, Editura Niculescu, București,.

9. Văideanu,G., (1986). Pedagogie-ghid pentru profesori, Editura Universității „Al. I. Cuza", Iași.

10. Vodanovich, Shahper; Sundaram, David; Ning, Shen, Kathy, (2015).Social Competence of Digital Natives: Impact of Social Networking Sites (SNS) Use, AIS Electronic Library. 